\title{
Co@CoO: a Unique Catalyst for Hydrogenolysis of Biomass- derived 5-Hydroxymethylfurfural to 2,5-Dimethylfuran
}

Shuang Xiang ${ }^{1,5}$, Lin Dong ${ }^{1,4,5}$, Zhi-Qiang Wang ${ }^{1,5}$, Xue Han ${ }^{2}$, Luke L. Daemen ${ }^{3}$, Yongqiang Cheng ${ }^{3}$, Yong Guo ${ }^{1}$, Xiaohui Liu ${ }^{1}$, Anibal J. Ramirez-Cuesta ${ }^{3}$, Sihai Yang ${ }^{2 *}$, Xue-Qing Gong ${ }^{1 *}$ and Yanqin $\mathrm{Wang}^{1 *}$

${ }^{1}$ Key Laboratory for Advanced Materials and Joint International Research Laboratory of Precision Chemistry and Molecular Engineering, Feringa Nobel Prize Scientist Joint Research Center, Research Institute of Industrial Catalysis, School of Chemistry and Molecular Engineering, East China University of Science and Technology, Shanghai, 200237, China.

2 Department of Chemistry, University of Manchester, Manchester, M13 9PL (UK)

${ }^{3}$ Neutron Scattering Division, Neutron Sciences Directorate, Oak Ridge National Laboratory, Oak Ridge, TN 37831 (USA)

${ }^{4}$ College of Chemical Engineering, Nanjing Forestry University, Nanjing 210037, China

5 These authors contributed equally

Corresponding authors: Sihai.Yang@manchester.ac.uk (S. Y.); xgong@ecust.edu.cn (X.Q.G); wangyaqin@ecust.edu.cn (Y. Q. W.) 
The development of precious-metal-free catalysts to promote the sustainable production of fuels and chemicals from biomass remains an important and challenging target. Here, we report the efficient hydrogenolysis of biomass-derived 5-hydroxymethylfurfural to 2,5-dimethylfuran over a unique core-shell structured catalyst $\mathrm{Co@CoO}$ that affords the highest productivity among all catalysts reported to date. Surprisingly, we found that the catalytically active sites reside on the shell of $\mathrm{CoO}$ with oxygen vacancies rather than the metallic Co. The combination of various spectroscopic experiments and computational modelling reveals that the $\mathrm{CoO}$ shell incorporating oxygen vacancies drives the heterolytic and homolytic cleavage of dihydrogen to yield active $\mathbf{H}^{\delta-}$ species, resulting in the exceptional catalytic activity. $\mathrm{Co} @ \mathrm{CoO}$ also exhibits excellent activity toward the direct hydrodeoxygenation of lignin model compounds. This study unlocks, for the first time, the potential of metal-oxide catalysts for the production of renewable biomass-derived fuels. 
Biomass is the only renewable resource of organic carbons in nature and their conversion to valueadded chemicals and liquid fuels is of vital importance in achieving global carbon neutralisation ${ }^{1,2}$. Cellulose-derived 5-hydroxymethylfurfural (HMF) is widely recognised as a platform chemical for the synthesis of sustainable liquid fuels and chemicals ${ }^{3,4}$. Particularly, the selective hydrogenolysis of HMF to 2,5-dimethylfuran (DMF) as biofuel has attracted much interest ${ }^{5,6}$. A great deal of effort has been devoted to developing supported metal catalysts for this reaction, and state-of-the-art catalysts are based upon $\mathrm{Ru}, \mathrm{Pd}, \mathrm{Pt}, \mathrm{Ni}, \mathrm{Cu}$ materials ${ }^{7-11}$. We have designed cobalt oxide-supported ruthenium $\left(\mathrm{Ru} / \mathrm{Co}_{3} \mathrm{O}_{4}\right)$ and cobalt/nickel $\left[(\mathrm{Co}) \mathrm{Ni} / \mathrm{Co}_{3} \mathrm{O}_{4}\right]$ catalysts that show DMF yields of $93 \%$ and $70-76 \%$, respectively, at $130{ }^{\circ} \mathrm{C}$ for $24 \mathrm{~h}^{7,8}$. Schüth et al. developed a hollow platinum-cobalt bimetallic nanoparticle (PtCo@HCS) catalyst, which achieved a high yield of DMF (98\%) at $180{ }^{\circ} \mathrm{C}$ for $2 \mathrm{~h}^{10}$. Esteves et al. investigated various supported copper catalysts and identified a high yield of DMF (93\%) over $\mathrm{Cu} / \mathrm{Fe}_{2} \mathrm{O}_{3}-\mathrm{Al}_{2} \mathrm{O}_{3}$ at $150{ }^{\circ} \mathrm{C}$ for $10 \mathrm{~h}^{11}$. To date, metal and harsh reaction condition (i.e., high temperature and/or long reaction time) are almost indispensable to achieve the high yield of DMF. It is widely accepted that the homolytic dissociation of $\mathrm{H}_{2}$ occurs on these metal catalysts, generating free radicals (H.) to drive the subsequent hydrogenolysis ${ }^{12}$. Recently, it is reported that $\mathrm{H}^{\delta-}$ species obtained via heterolytic dissociation of $\mathrm{H}_{2}$ showed enhanced catalytic performance ${ }^{13-17}$. Thus, the development of new catalysts that can generate $\mathrm{H}^{\delta-}$ species hold great promise to promote the hydrogenolysis of $\mathrm{HMF}$ under mild reaction conditions.

Although single-atom catalysts can catalyse the heterolytic cleavage of $\mathrm{H}_{2}{ }^{13-15}$, there is complicity associated with their preparation and thermodynamic stability. Meanwhile, metal oxides with a high concentration of surface defects are reported as emerging catalysts with high activity for the heterolytic cleavage of $\mathrm{H}_{2}{ }^{16-22}$. For example, ceria with oxygen vacancies $\left(\mathrm{O}_{\mathrm{v}}\right)$ can produce $\mathrm{H}^{\delta-}$ species via the 
heterolytic pathway and showed excellent activity in hydrogenation reactions ${ }^{16,17}$, where the oxygen vacancies played an important role in the formation and stabilisation of hydride species $\left(\mathrm{Ce}_{\mathrm{Ov}}{ }^{4+}-\mathrm{H}^{-}\right)^{18}$. However, metal oxides that can promote hydrogenolysis via integrated homolytic and heterolytic cleavage of $\mathrm{H}_{2}$ have not been reported to date.

Here, we report an unusual core-shell structured catalyst, $\mathrm{Co} @ \mathrm{CoO}$, which can promote the integrated homolytic and heterolytic cleavage of $\mathrm{H}_{2}$, affording an exceptional performance for the hydrogenolysis of HMF to DMF under mild conditions. Importantly, a superior productivity of DMF $\left(17.58 \mathrm{mmol} \cdot \mathrm{g}^{-1} \mathrm{~h}^{-1}\right)$ was achieved over $\mathrm{Co} @ \mathrm{CoO}$ at $130{ }^{\circ} \mathrm{C}$. Moreover, $\mathrm{Co} @ \mathrm{CoO}$ demonstrated an excellent catalytic stability of over 100 hours in a continuous flow reaction at a space velocity as high as $26.6 \mathrm{~h}^{-1}$. Transmission electron microscopy (TEM), X-ray photoelectron spectroscopy (XPS), inelastic neutron scattering (INS) and density functional theory (DFT) calculations confirm that the superior catalytic performance is attributed to the $\mathrm{CoO}$ shell decorated with oxygen vacancies. It not only catalyses the homolytic/heterolytic cleavage of $\mathrm{H}_{2}$ to generate $\mathrm{H}^{\delta-}$ species, but also promotes the adsorption and activation of HMF. Co@CoO also exhibits an excellent performance for the hydrogenolysis of the lignin $\beta$-O-4 model compound. This study will inspire the design of new efficient catalysts based upon precious-metal-free metal oxides to promote the synthesis of renewable biofuels.

\section{Result}

Hydrogenolysis of HMF to DMF. The hydrogenolysis of HMF was firstly conducted in a batch reactor at $130{ }^{\circ} \mathrm{C}$ with $1 \mathrm{MPa} \mathrm{H}_{2}$ for $2 \mathrm{~h}$ over a series of $\mathrm{Co}_{3} \mathrm{O}_{4}$-temp. (temp. = temperature for reduction in ${ }^{\circ} \mathrm{C}$ ) catalysts, which are prepared by a simple precipitation method followed by reduction in $10 \% \mathrm{H}_{2}$ for $2 \mathrm{~h}$ (see Methods). It is reported that the hydrogenolysis of HMF to DMF over supported metal catalysts proceeds through the hydrogenation of $\mathrm{C}=\mathrm{O}$ to $\mathrm{C}-\mathrm{OH}$ group to give 2,5-furandimethanol (BHMF), 
which is followed by the hydrogenolysis of $\mathrm{C}-\mathrm{OH}$ groups to 5-methyl-2-furanmethanol (HMMF) and DMF ${ }^{5,6}$. The reaction pathway over $\mathrm{Co}_{3} \mathrm{O}_{4}-250$ followed the reported route and HMMF was the main intermediate (Supplementary Figure 1). Among all the investigated catalysts, $\mathrm{Co}_{3} \mathrm{O}_{4}-250$ shows the best catalytic performance and the yield of DMF reaches $89 \%$ on full conversion of HMF (Table 1). Unreduced $\mathrm{Co}_{3} \mathrm{O}_{4}$ and $\mathrm{Co}_{3} \mathrm{O}_{4}-200$ catalysts give no activity. $\mathrm{Co}_{3} \mathrm{O}_{4}-300$ and $\mathrm{Co}_{3} \mathrm{O}_{4}-400$ show poor activity with HMMF and BHMF being the main product, respectively, and the yield of DMF over $\mathrm{Co}_{3} \mathrm{O}_{4}-400$ only reached $71 \%$ even with prolonged reaction time of $24 \mathrm{~h}$. These differences in activity clearly indicates that the extent of reduction of $\mathrm{Co}_{3} \mathrm{O}_{4}$ plays a key role in determining its structure and hence the activity of the catalysts.

A small amount of HMMF (4.3\%) was detected over $\mathrm{Co}_{3} \mathrm{O}_{4}-250$ in the first $2 \mathrm{~h}$ of the reaction, and this can be further converted into DMF with a total yield of $92 \%$ in $3 \mathrm{~h}$. At $100{ }^{\circ} \mathrm{C}$, a DMF yield of $54.9 \%$ was obtained over $\mathrm{Co}_{3} \mathrm{O}_{4}-250$ in $6 \mathrm{~h}$ (Supplementary Table 1). At 150 and $180{ }^{\circ} \mathrm{C}$, the reaction was conducted with twice amount of the substrate of HMF due to the accelerated reaction kinetics and the yield of DMF was $73 \%$ and $53 \%$, respectively (Supplementary Table 1). The productivities are calculated (Fig. 1a) and importantly, $\mathrm{Co}_{3} \mathrm{O}_{4}-250$ shows remarkably high productivities across the temperature range of $100-250^{\circ} \mathrm{C}$, outperforming all state-of-the-art metal-based catalysts ${ }^{7,8,10,11,23-40}$.

The excellent stability of $\mathrm{Co}_{3} \mathrm{O}_{4}-250$ for the conversion of HMF to DMF has been demonstrated by a continuous flow reaction over $100 \mathrm{~h}$ (Fig. 1b). To further examine the catalytic stability, the weight hourly space velocity (WHSV) is increased to $26.6 \mathrm{~h}^{-1}$, much higher than that $\left(3.3 \mathrm{~h}^{-1}\right)$ over $2 \% \mathrm{Ni}$ $20 \% \mathrm{Co} / \mathrm{C}$ catalyst $^{33}$ and other reports ${ }^{41,42}$. Significantly, $\mathrm{Co}_{3} \mathrm{O}_{4}-250$ shows excellent activity and stability with little decrease in DMF yield (>75\%). In addition, TEM images suggests an absence of notable structural change of $\mathrm{Co}_{3} \mathrm{O}_{4}-250$ post the $100 \mathrm{~h}$ time-on-stream test (Supplementary Figure 2). 
Table 1. Summary of results of conversion of HMF over different Co-based catalysts.

\begin{tabular}{|c|c|c|c|c|c|c|}
\hline HМF & & IMF & & IMMF & & DMF \\
\hline \multirow{3}{*}{ Catalyst } & \multicolumn{5}{|c|}{ Yield (\%) } & \multirow{3}{*}{$\begin{array}{l}\text { DMF } \\
\text { productivity } \\
/ \mathrm{mmol} \cdot \mathrm{g}^{-1} \mathrm{~h}^{-1}\end{array}$} \\
\hline & \multirow[t]{2}{*}{ Conv. $(\%)$} & & & & & \\
\hline & & BHMF & HMMF & DMF & others & \\
\hline $\mathrm{Co}_{3} \mathrm{O}_{4}$ & 1.9 & 0.0 & 0.0 & 0.0 & 0.0 & 0.0 \\
\hline $\mathrm{Co}_{3} \mathrm{O}_{4}-200$ & 2.4 & 0.0 & 0.0 & 0.0 & 0.0 & 0.0 \\
\hline $\mathrm{Co}_{3} \mathrm{O}_{4}-250$ & $>99$ & 0.0 & 4.3 & 89.2 & 0.0 & 17.6 \\
\hline $\mathrm{Co}_{3} \mathrm{O}_{4}-300$ & $>99$ & 0.0 & 54 & 39.0 & 1.2 & 7.7 \\
\hline $\mathrm{Co}_{3} \mathrm{O}_{4}-400$ & 91 & 65.0 & 16 & 2.9 & 1.3 & 0.5 \\
\hline $\mathrm{Co}_{3} \mathrm{O}_{4}-400^{\mathrm{a}}$ & $>99$ & 6.7 & 17 & 71.0 & 0.3 & 1.2 \\
\hline Commercial CoO & 1.2 & 0.0 & 0.0 & 0.0 & 0.0 & 0.0 \\
\hline Commercial CoO-reduced & 60.0 & 45.0 & 4.3 & 1.1 & 2.2 & 8.9 \\
\hline
\end{tabular}

Reaction conditions: HMF (150 mg), catalyst (30 mg), THF (5 mL), $\mathrm{H}_{2}$ pressure (1 MPa), Temperature $\left(130^{\circ} \mathrm{C}\right), 2 \mathrm{~h}$.

a $24 \mathrm{~h}$ 

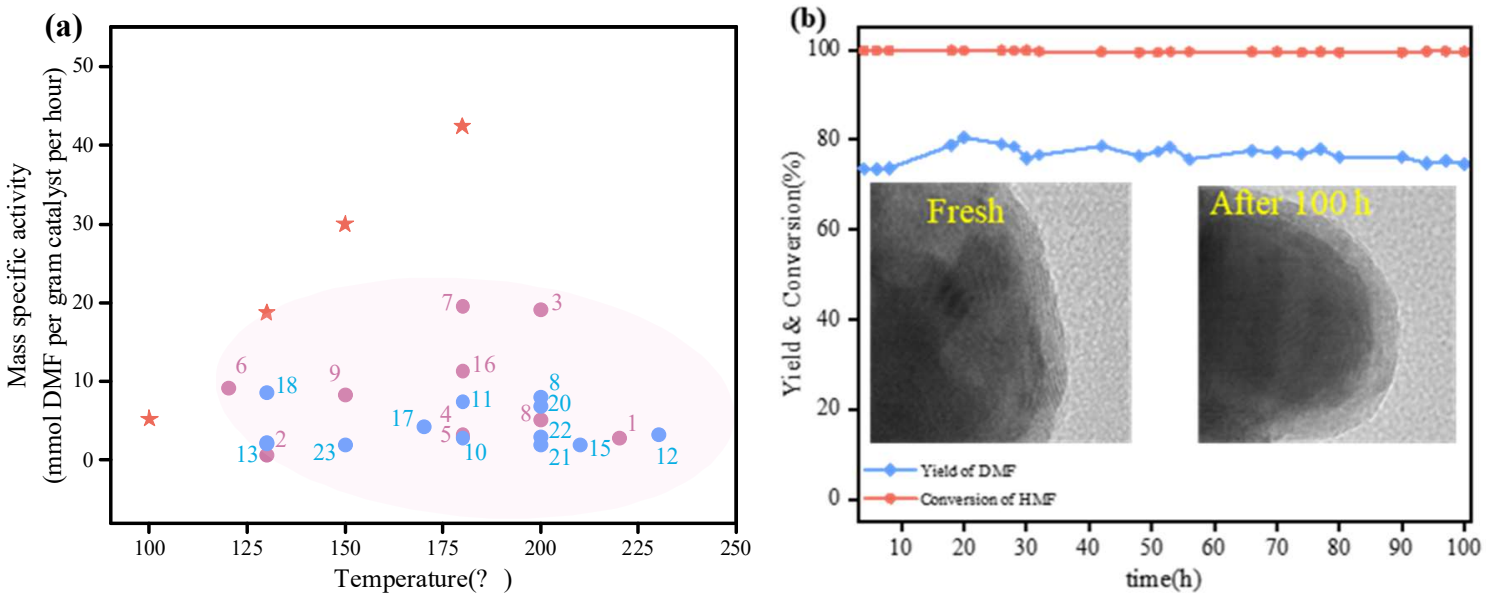

Fig. 1. (a) Comparison of the catalytic performance of all state-of-the-art catalysts for the hydrogenolysis of HMF to DMF. A summary of the productivities of representative noble-metal catalysts (purple circles), non-noble-metal catalysts (blue circles), $\mathrm{Co}_{3} \mathrm{O}_{4}-250$. Full data is shown in Table S1. (1) Ru-doped hydrotalcite ${ }^{23}$; (2) $\mathrm{Ru} / \mathrm{Co}_{3} \mathrm{O}_{4}{ }^{7}$; (3) $\mathrm{RuCo} / \mathrm{CoO}_{\mathrm{x}}{ }^{24}$; (4) $\mathrm{Ru} / \mathrm{CoFe}-\mathrm{LDO}^{25}$; (5) $\mathrm{Pt}_{1} / \mathrm{Co}^{26}$; (6) $\mathrm{Pt} / \mathrm{rGO}^{27}$; (7) PtCo@HCS ${ }^{10}$; (8) Pd-OMD1/Ni-OMD1 ${ }^{28}$; (9) Pd/C/Zne ${ }^{29}$; (10) Raney $\mathrm{Co}^{30}$; (11) Ni/C ${ }^{31}$; (12) Ni/LaFeO ${ }^{32}$; (13) Ni-Co oxides ${ }^{8}$; (14) Ni-Co/C $\mathrm{C}^{33}$; (15) 2\%Ni-20\%Co/C ${ }^{34} ;$ (16) Ag-Co@ $\mathrm{C}^{35}$; (17) $\mathrm{Co}^{-\mathrm{CoO}_{\mathrm{x}}}{ }^{36}$; (18) Co/Mix-ZrO ${ }_{2}^{37}$; (19) $\mathrm{CuZn}^{38}$; (20) $\mathrm{Cu}-\mathrm{Ni} / \mathrm{Al}_{2} \mathrm{O}_{3}{ }^{39} ;$ (21) $\mathrm{CuNi} / \mathrm{TiO}_{2}{ }^{40} ;$ (22) $\mathrm{Cu} / \mathrm{Fe}_{2} \mathrm{O}_{3}-\mathrm{Al}_{2} \mathrm{O}_{3}{ }^{11}$. (b) Catalytic performance and stability of the hydrogenolysis of HMF to DMF. Reaction conditions: $130{ }^{\circ} \mathrm{C}, 1 \mathrm{MPa}$ of $\mathrm{H}_{2}, 26.6 \mathrm{~h}^{-1}$ WHSV and $30 \mathrm{~mL} \min ^{-1} \mathrm{H}_{2}$ gas flow rate.

Catalyst characterisation. To investigate the effect of reduction temperature to the structure of the catalysts, high resolution TEM images was taken with all Co-based catalysts, and significant differences in composition and crystal structure were observed (Fig. 2a). The unreduced $\mathrm{Co}_{3} \mathrm{O}_{4}$ catalyst shows the interplanar crystal spacing of $0.285 \mathrm{~nm}$, corresponding to the (220) plane of the spinel structured $\mathrm{Co}_{3} \mathrm{O}_{4}$. While $\mathrm{Co}_{3} \mathrm{O}_{4}-200$ and $\mathrm{Co}_{3} \mathrm{O}_{4}-250$ both show core-shell structures, the former is $\mathrm{CoO} @ \mathrm{Co}_{3} \mathrm{O}_{4}$ and the latter is $\mathrm{Co} @ \mathrm{CoO}$. Importantly, $\mathrm{Co}_{3} \mathrm{O}_{4}-250$ has a tight $\mathrm{CoO}$ shell and this core-shell structure was observed uniformly over the $\mathrm{Co}_{3} \mathrm{O}_{4}-250$ sample (Fig. 2b). While over the $\mathrm{Co}_{3} \mathrm{O}_{4}-300$ catalyst, the $\mathrm{CoO}$ 
shell becomes thinner and generates a minor amount of metallic Co on the surface. These results indicate that the reduction of $\mathrm{Co}_{3} \mathrm{O}_{4}$ takes places from the core, and the phase composition and morphology are evolved from spherical $\mathrm{Co}_{3} \mathrm{O}_{4}$ to core-shelled $\mathrm{CoO} @ \mathrm{Co}_{3} \mathrm{O}_{4}$, then to core-shelled $\mathrm{Co} @ \mathrm{CoO}$ with different thickness of the shell.

(a)

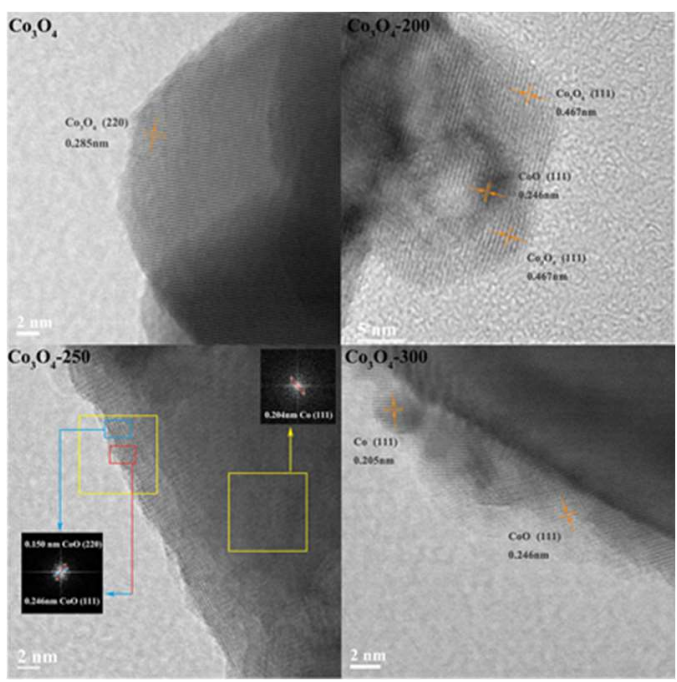

(b)

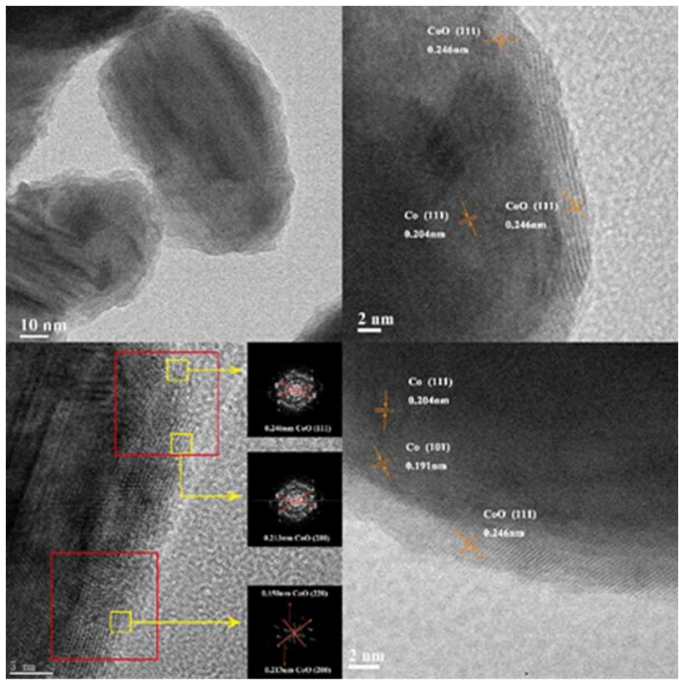

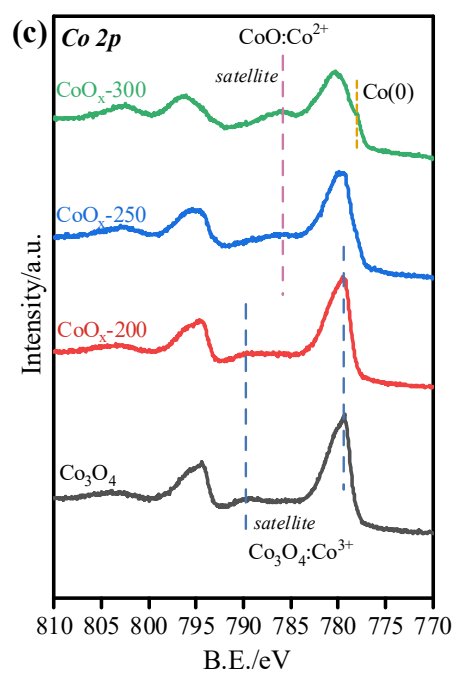
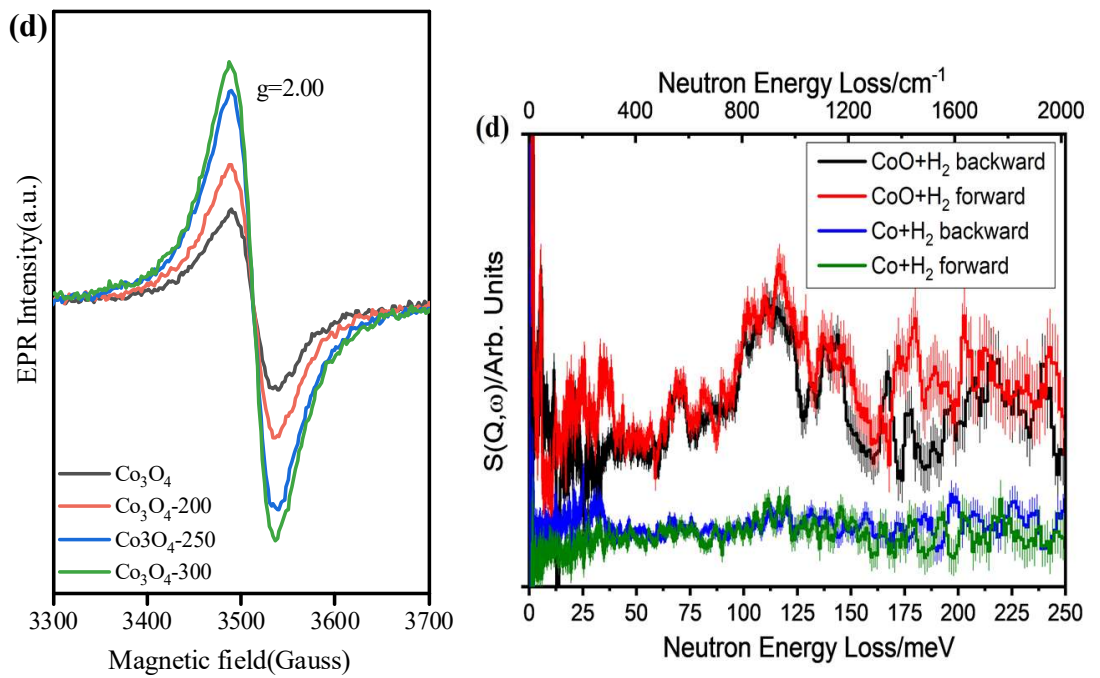

Fig. 2. (a) HRTEM images of selected catalysts; (b) Representative HRTEM images of $\mathrm{Co}_{3} \mathrm{O}_{4}-250$;

(c) XPS spectra of the Co 2p orbital; (d) X-band EPR spectra of unreduced $\mathrm{Co}_{3} \mathrm{O}_{4}, \mathrm{Co}_{3} \mathrm{O}_{4}-200, \mathrm{Co}_{3} \mathrm{O}_{4}-$ 250 and $\mathrm{Co}_{3} \mathrm{O}_{4}-300$ at $77 \mathrm{~K}$; (e) Comparison of the difference INS spectra of the $\mathrm{Co}_{3} \mathrm{O}_{4}-250$ and $\mathrm{Co}$ catalysts upon hydrogenation showing unique signals of hydrogenous species on $\mathrm{Co}_{3} \mathrm{O}_{4}-250$. The difference spectra are obtained by subtracting the INS spectrum of fresh catalyst from that of the 
hydrogenated catalyst. Raw INS spectra are shown in Supplementary Figure 4 and Figure 5.

XRD analysis was also conducted to characterise the phases of these catalysts (Supplementary Figure 3). For unreduced $\mathrm{Co}_{3} \mathrm{O}_{4}$, only spinel-phase $\mathrm{Co}_{3} \mathrm{O}_{4}$ (PDF\#42-1003) was observed. The main phase of $\mathrm{Co}_{3} \mathrm{O}_{4}-200$ is spinel-phase $\mathrm{Co}_{3} \mathrm{O}_{4}$ with a small amount of cubic-phase $\mathrm{CoO}$ (PDF\#48-1719). The XRD patterns of $\mathrm{Co}_{3} \mathrm{O}_{4}-250$ and $\mathrm{Co}_{3} \mathrm{O}_{4}-300$ show a mixture of cubic phases of $\mathrm{Co}$ and $\mathrm{CoO} . \mathrm{Co}_{3} \mathrm{O}_{4}-$ 400 shows a primarily metallic Co structure with little catalytic activity. The TEM and XRD results indicate that the shell of $\mathrm{CoO}$ acts as the active sites for the hydrogenolysis of HMF.

To further explore the electronic properties of surface Co species, XPS spectra of all samples were recorded (Fig. 2c). The binding energy, shape and intensity of the satellite peaks are used to identify the cobalt species ${ }^{43,44}$, because the satellite peaks associated with the Co $2 \mathrm{p}_{3 / 2}$ peaks of $\mathrm{Co}_{3} \mathrm{O}_{4}$ and $\mathrm{CoO}$ are distinct ${ }^{45} . \mathrm{Co}_{3} \mathrm{O}_{4}$ and $\mathrm{Co}_{3} \mathrm{O}_{4}-200$ both exhibit peaks at $779.9 \mathrm{eV}$ and $796.7 \mathrm{eV}$, which are attributed to $\mathrm{Co}^{3+}$ of $\mathrm{Co}_{3} \mathrm{O}_{4}$. While $\mathrm{Co}_{3} \mathrm{O}_{4}-250$ shows a strong satellite peak of $\mathrm{Co} 2 \mathrm{p}_{3 / 2}$ at $786.0 \mathrm{eV}$, indicating the presence of $\mathrm{CoO}$ on the surface. An additional peak appeared at $778.0 \mathrm{eV}$ for $\mathrm{Co}_{3} \mathrm{O}_{4}-300$, which belongs to metallic Co, confirming the coexistence of both metallic $\mathrm{Co}$ and $\mathrm{CoO}$ on the surface. Thus, the XPS study confirms the presence of a shell of $\mathrm{CoO}$ on $\mathrm{Co}_{3} \mathrm{O}_{4}-250$.

It is reported that the concentration and location of oxygen vacancy in $\mathrm{CeO}_{2}$ play an important role in its activity for hydrogenation reactions ${ }^{16-18}$. Commercial $\mathrm{CoO}$ and its pre-reduced analogue (250 $\left.{ }^{\circ} \mathrm{C}\right)$ were used to further clarify the importance of surface defects, and the results are summarized in Table 1. Negligible conversion was observed with commercial $\mathrm{CoO}$, and with the reduced commercial $\mathrm{CoO}$, the yield of BHMF and DMF is $44.6 \%$ and $1.1 \%$, respectively. To study the oxygen vacancy of these Co-based catalysts, X-band continuous wave electron paramagnetic resonance (EPR) spectra were collected at $77 \mathrm{~K}$. Compared with $\mathrm{Co}_{3} \mathrm{O}_{4}-200$, the signal at $\mathrm{g}=2.00$ appeared and is gradually enhanced 
upon increase of the reduction temperature from 200 to $300{ }^{\circ} \mathrm{C}$, demonstrating the increased concentration of oxygen vacancies (Fig. 2d).

In situ INS was conducted to examine the formation of cobalt hydride upon the activation of $\mathrm{H}_{2}$ over $\mathrm{Co}_{3} \mathrm{O}_{4}-250$. Comparison of the difference of INS spectra before and after the dissociation of $\mathrm{H}_{2}$ over $\mathrm{Co}_{3} \mathrm{O}_{4}-250$ (that is, signals for intermediates that may form under the conditions of the hydrogenation reaction) showed a number of marked changes (Fig. 2e). The main feature (I) centred at $110 \mathrm{meV}$ evidently indicates the formation of $\mathrm{Co}-\mathrm{H}$ species $^{46}$. A broad underlining intensity across $80-$ $160 \mathrm{meV}$ is also observed, and this can be assigned to the formation of Co-O-H, as previously observed with a $\mathrm{CuCrFeO}_{\mathrm{x}}$ catalyst $^{47}$. The sharp features above $160 \mathrm{meV}$ are unlikely caused by any $\mathrm{H}$-containing species formed under reaction conditions because of the inconsistent intensities detected for this region by the forward and backward detectors (Fig. 2e). These results hint heterolytic splitting of $\mathrm{H}_{2}$ has occurred. To gain further insights, the in situ INS experiment was also carried out with the metallic Co catalyst $\left(\mathrm{Co}_{3} \mathrm{O}_{4}-400\right)$, and upon reacting with $\mathrm{H}_{2}$ under same conditions, no distinct features were observed for $\mathrm{Co}_{3} \mathrm{O}_{4}-400$, indicating that the presence of surface $\mathrm{Co}-\mathrm{O}$ and $\mathrm{O}$ vacancy is crucial for the formation Co-H intermediates. Therefore, the unique $\mathrm{Co} @ \mathrm{CoO}$ core-shell structure of $\mathrm{Co}_{3} \mathrm{O}_{4}-250$ with rich oxygen vacancy directly promotes the formation of $\mathrm{H}^{\delta-}$ species.

Density functional theory studies. To elucidate the excellent activity and importance of oxygen vacancy on the $\mathrm{CoO}$ shell of $\mathrm{Co}_{3} \mathrm{O}_{4}-250$ for the hydrogenolysis of $\mathrm{HMF}$, theoretical investigations using electronic density functional theory (DFT) method were carried out. All calculations were performed with Vienna Ab initio Simulation Package (VASP) (see Methods). We first built the $p(2 \times 3)$ surface slabs with six atom layers for the stoichiometric $\mathrm{CoO}(100)$ and $\mathrm{CoO}(100)-\mathrm{Ov}$ surfaces. The calculated oxygen vacancy formation energy of the $\mathrm{CoO}(100)$ surface is $5.77 \mathrm{eV}$ (Supplementary Figure 6). Then, 
the energy profiles of the adsorption and dissociation of $\mathrm{H}_{2}$ on the $\mathrm{CoO}(100)$ and $\mathrm{CoO}(100)-\mathrm{Ov}$ surfaces were calculated (Fig. 3a, Supplementary Figure 7 and Supplementary Table 2). Firstly, the adsorption energies of $\mathrm{H}_{2}$ at $\mathrm{CoO}(100)$ and $\mathrm{CoO}(100)-\mathrm{Ov}$ were calculated to be $0.25 \mathrm{eV}$ and $1.63 \mathrm{eV}$, respectively, indicating that $\mathrm{CoO}(100)-\mathrm{Ov}$ possesses a stronger binding ability. Subsequently, the dissociation of $\mathrm{H}_{2}$ in a heterolytic way was calculated. This process is endothermic by $0.54 \mathrm{eV}$ and gives a barrier of 0.60 eV over $\mathrm{CoO}(100)$, while on the $\mathrm{CoO}(100)-\mathrm{O}_{\mathrm{v}}$ surface it is less endothermic $(0.36 \mathrm{eV})$ and with a lower barrier of $0.56 \mathrm{eV}$. Therefore, the $\mathrm{CoO}(100)-\mathrm{O}_{\mathrm{v}}$ appears to be more beneficial for $\mathrm{H}_{2}$ dissociation in the heterolytic way. For more comprehensive understanding, we also calculated the homolytic dissociation of $\mathrm{H}_{2}$ on the $\mathrm{CoO}(100)-\mathrm{O}_{v}$ surface (Supplementary Figure 7). Surprisingly, the $\mathrm{H}_{2}$ on the $\mathrm{CoO}(100)-\mathrm{O}_{\mathrm{V}}$ surface was split into two $\mathrm{H}^{\delta-}$ with the help of the $\mathrm{O}_{\mathrm{v}}$, as confirmed by the Bader charge analysis (Supplementary Figure 7), and such homolytic dissociation of $\mathrm{H}_{2}$ is calculated to be exothermic $(0.23$ $\mathrm{eV}$ ) and with an energy barrier of $0.51 \mathrm{eV}$. This indicates that the homolytic dissociation is easier than the heterolytic one and the formation of two $\mathrm{H}^{\delta-}$ may make the $\mathrm{CoO}(100)-\mathrm{O}_{\mathrm{V}}$ surface more active than $\mathrm{CoO}(100)$.

The adsorption structures and energetics of HMF on the $\mathrm{CoO}(100)$ and $\mathrm{CoO}(100)-\mathrm{Ov}$ surfaces were also calculated for comparison (Fig. 3a and Supplementary Figure 8). One can clearly see from the figures that (i) HMF can be parallelly and vertically adsorbed on the two surfaces and the calculated adsorption energies at $\mathrm{CoO}(100)-\mathrm{O}_{\mathrm{v}}$ are higher than those at $\mathrm{CoO}(100)$, indicating that the $\mathrm{CoO}(100)-$ $\mathrm{O}_{\mathrm{v}}$ possesses a stronger binding ability; (ii) over the $\mathrm{CoO}(100)$ surface, the calculated highest adsorption energy is only $0.24 \mathrm{eV}$, in agreement with the poor activity of the commercial $\mathrm{CoO}$ catalysts; (iii) the adsorption through the $\mathrm{C}=\mathrm{O}$ group is stronger than that through $\mathrm{C}-\mathrm{OH}$ group over the $\mathrm{CoO}(100)-\mathrm{Ov}$ surface, which may promote the first hydrogenation of HMF to BHMF, followed by hydrogenolysis to HHMF and DMF over the $\mathrm{Co}_{3} \mathrm{O}_{4}-250$ catalyst. 
Then, the rather strong adsorption for $\mathrm{H}_{2}(1.63 \mathrm{eV})$ at $\mathrm{CoO}(100)-\mathrm{O}_{\mathrm{v}}$ as well as the existence of large number of active $\mathrm{H}^{\delta-}$ species involved in this reaction can support the excellent activity of $\mathrm{Co}_{3} \mathrm{O}_{4-}$ 250.
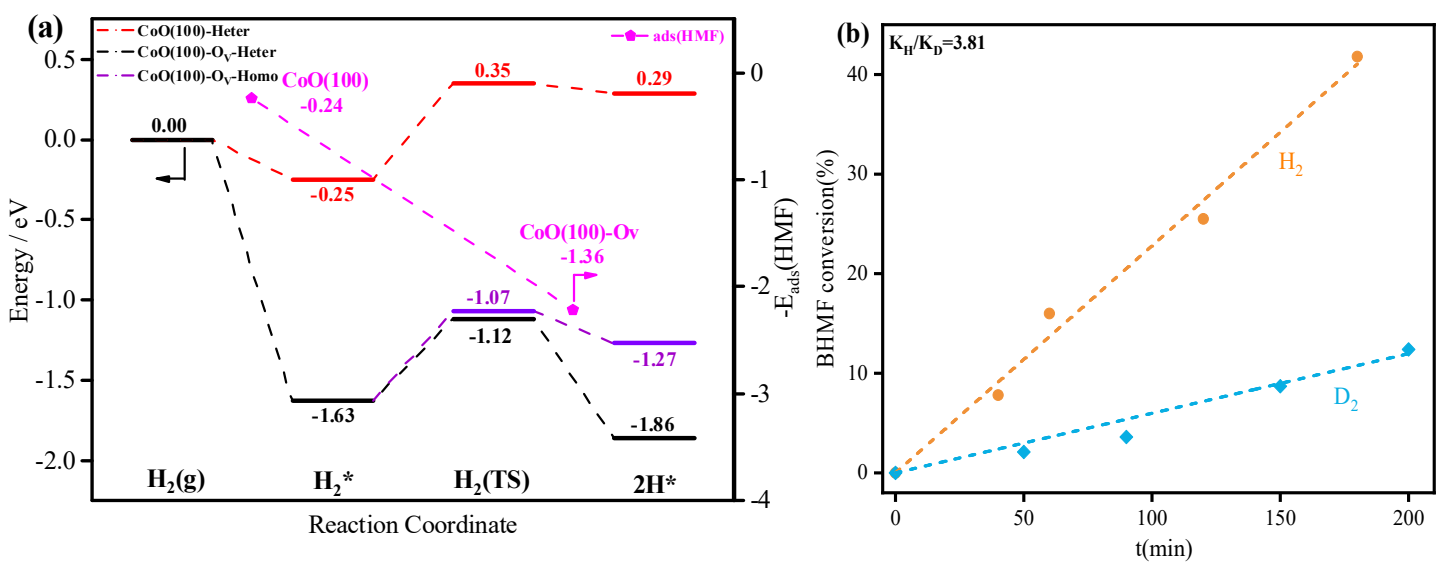

Fig. 3. (a) Calculated energy profiles of adsorption and dissociation of $\mathrm{H}_{2}$ and adsorption of HMF on the $\mathrm{CoO}(100)$ and $\mathrm{CoO}(100)-\mathrm{O}_{\mathrm{v}}$ surfaces. $\mathrm{H}_{2}(\mathrm{~g})$ : gas-phase $\mathrm{H}_{2} ; \mathrm{H}_{2}{ }^{*}$ : adsorbed $\mathrm{H}_{2}$ on surface; $\mathrm{H}_{2}(\mathrm{TS})$ : the adsorbed $\mathrm{H}_{2}$ on surface dissociates to two adsorbed $\mathrm{H}$ on surface; $2 \mathrm{H}^{*}$ : the co-adsorption of two $\mathrm{H}$ on surface; (b) primary kinetic isotope effect observed for the HDO of 2,5-furandimethanol (BHMF). Reaction condition: BHMF, $200 \mathrm{mg}$; catalyst $\left(\mathrm{Co}_{3} \mathrm{O}_{4}-250\right), 20 \mathrm{mg}$; THF, $5 \mathrm{~mL}$; temperature, $130{ }^{\circ} \mathrm{C}$; $\mathrm{H}_{2} / \mathrm{D}_{2}, 1 \mathrm{MPa}$.

Kinetic studies of the activation of $\mathrm{H}_{2}$ over $\mathrm{Co}_{3} \mathrm{O}_{4}-250$. The study of reaction pathway (Supplementary Figure 1) shows that HMMF was the main intermediate. Therefore, kinetic studies on the hydrogenolysis of HMMF were carried out. The hydrogenolysis of HMMF has a reaction order of ca. 0.9 for $\mathrm{H}_{2}$, but close to 0 for HMMF, indicating that the activation of $\mathrm{H}_{2}$ instead of HMMF is the rate-determining step (Supplementary Figure 9), in agreement with the DFT analysis. With $\mathrm{D}_{2}$, the reaction rate decreased by around 3.8 times (Fig. 3b), confirming that the activation of $\mathrm{H}_{2} / \mathrm{D}_{2}$ is involved in the rate-determining step. Meanwhile, the reaction rate with $\mathrm{D}_{2}$ over $\mathrm{Co}_{3} \mathrm{O}_{4}-400$ was slowed down by a factor of 2.22 comparing to that with $\mathrm{H}_{2}$, due to the difference in zero-point energy between the 
isotopic isomers (Supplementary Figure 10) ${ }^{13}$.

Hydrodeoxygenation of a lignin model compound over $\mathrm{Co}_{3} \mathrm{O}_{4}-250$. To further verify the applicability of $\mathrm{Co}_{3} \mathrm{O}_{4}-250$ for the hydrodeoxygenation (HDO) of more robust biomass-derived feedstocks, the typical lignin $\beta$-O-4 model compound was tested (Fig. 4). Complete conversion of lignin $\beta-\mathrm{O}-4$ model compound was observed at $180{ }^{\circ} \mathrm{C}$ for $8 \mathrm{~h}$ with high carbon yields, affording $85.5 \%$ ethylbenzene and $84.5 \%$ cyclohexanol. Significantly, this is the first report of the reductive cleavage of $\beta-\mathrm{O}-4$ linkage over metal oxides. In contrast, other $\mathrm{Co}_{3} \mathrm{O}_{4}$ catalysts with varying reduction temperatures all show poor activity for HDO of the lignin $\beta-\mathrm{O}-4$ model compound (Supplementary Table 3). This result further confirms that $\mathrm{Co}_{3} \mathrm{O}_{4}-250$ has an excellent activity for the hydrogenation of $\mathrm{C}=\mathrm{C} / \mathrm{C}=\mathrm{O}$ bonds and hydrogenolysis of C-O bonds in biomass-derived substrates.

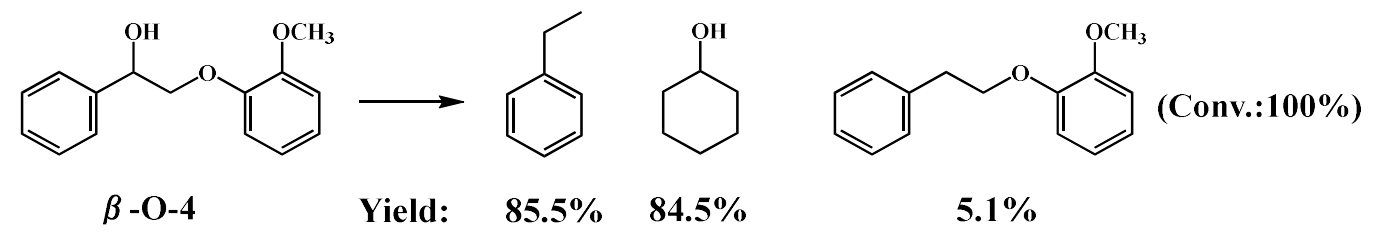

Fig. 4. Hydrogenolysis of the lignin $\beta-\mathrm{O}-4$ model compound over the $\mathrm{Co}_{3} \mathrm{O}_{4}-250$ catalyst. Reaction conditions: substrate $(0.2 \mathrm{~g})$, catalyst $(0.1 \mathrm{~g}), 1,4$-dioxane $(5 \mathrm{~mL}), \mathrm{H}_{2}$ pressure $(0.5 \mathrm{MPa})$, temperature $\left(180^{\circ} \mathrm{C}\right), 8 \mathrm{~h}$.

\section{Conclusion}

A core-shell structured $\mathrm{Co} @ \mathrm{CoO}$ catalyst $\left(\mathrm{Co}_{3} \mathrm{O}_{4}-250\right)$ with oxygen vacancies in the shell of $\mathrm{CoO}$ showed an excellent activity in the hydrogenolysis of $\mathrm{HMF}$ to DMF. $\mathrm{Co}_{3} \mathrm{O}_{4}-250$ exhibited a high DMF yield of $89 \%$ at $130{ }^{\circ} \mathrm{C}$ for $2 \mathrm{~h}$, and the productivity is highest among all state-of-the-art catalysts to date. $\mathrm{Co}_{3} \mathrm{O}_{4}-250$ shows an excellent catalytic stability for over $100 \mathrm{~h}$ without notable deactivation at a high WHSV of $26.6 \mathrm{~h}^{-1}$. The superior activity of the $\mathrm{Co} @ \mathrm{CoO}$ catalyst originates from the unique CoO species with suitable oxygen vacancies, which can strongly adsorb HMF and catalyse the 
homolytic/heterolytic splitting of $\mathrm{H}_{2}$ molecules to produce highly active $\mathrm{H}^{\delta-}$ species. This study will inspire the design of new metal-free catalysts based upon metal oxides for the hydrogenation and hydrogenolysis reactions.

\section{Methods}

\section{Catalyst preparation}

$\mathrm{Co}_{3} \mathrm{O}_{4}$ was synthesized with a precipitation method. Cobalt nitrate is used as the synthetic precursor. In the typical process, $60 \mathrm{mmol}$ of cobalt nitrate and $69 \mathrm{mmol}$ of $\left(\mathrm{NH}_{4}\right)_{2} \mathrm{CO}_{3}$ was dissolved in $200 \mathrm{ml}$ distilled water, respectively. Then the solution of $\left(\mathrm{NH}_{4}\right)_{2} \mathrm{CO}_{3}$ was added dropwise into the aqueous solution of cobalt salt under vigorous stirring until the $\mathrm{pH}$ of the mother liquid reached approximately 9. Finally, the suspension was aged at $65{ }^{\circ} \mathrm{C}$ for $1 \mathrm{~h}$ with stirring and then left to stand at room temperature for $12 \mathrm{~h}$. After filtration and thoroughly washed with distilled water, the solid product was dried at $100{ }^{\circ} \mathrm{C}$ for $12 \mathrm{~h}$ and then calcined in air at $450{ }^{\circ} \mathrm{C}$ for $4 \mathrm{~h}$ to obtain $\mathrm{Co}_{3} \mathrm{O}_{4}$.

The as-prepared $\mathrm{Co}_{3} \mathrm{O}_{4}$ was further reduced at desired temperature $\left(200-400{ }^{\circ} \mathrm{C}\right)$ for $2 \mathrm{~h}$ under flowing $\mathrm{H}_{2}\left(10 \% \mathrm{H}_{2}\right.$-Ar mixed gas) in tube furnace with a ramp of $5{ }^{\circ} \mathrm{C} \cdot \mathrm{min}^{-1}$ before use. Thus-obtained reduced cobalt oxides were marked as $\mathrm{Co}_{3} \mathrm{O}_{4}-\mathrm{n}$, in which $\mathrm{n}$ represents the reduction temperature.

\section{Catalyst activity tests in batch reactor}

Hydrogenolysis of HMF was carried out in a Teflon-lined stainless-steel autoclave (50 mL). After sealing the desired dosage of HMF, catalyst and solvent in the reactor, the autoclave was purged with $\mathrm{H}_{2}$ three times to remove air and charged with the desired $\mathrm{H}_{2}$ pressure. Then, the autoclave was heated to the predetermined temperature in a short time. After reaction, the reactor was quenched in an icewater bath immediately. The liquid phase was separated from the solid catalyst by centrifugation, and two individual GC/GC-MS systems were used for product analyses. The qualitative analysis of products 
was carried out on a GC-MS system (Agilent 7890A-5975C), and the quantitative analysis was executed on a GC system (Agilent 7890B) equipped with an HP-5 column and an FID detector.

\section{Catalyst characterization}

The electron paramagnetic resonance (EPR) spectra were collected on a Bruker A300 spectrometer at $77 \mathrm{~K}$.

Inelastic neutron scattering (INS) spectra were recorded on the VISION spectrometer at the Spallation Neutron Source, Oak Ridge National Laboratory (USA). VISION is an indirect geometry crystal analyser instrument that provide a wide dynamic range with high resolution. All the INS spectra were collected after the sample was cooled and stabilised at temperatures below $10 \mathrm{~K}$. In a typical experiment, the catalyst $\mathrm{CoO}(\sim 10 \mathrm{~g})$ was loaded into a flow-type stainless steel cell that can also be used as a static cell with all valves closed. The sample was heated at $250{ }^{\circ} \mathrm{C}\left(5^{\circ} \mathrm{C} / \mathrm{min}\right.$ ramping $)$ under dry He for $1 \mathrm{~h}$ to remove any remaining trace water before the experiment. An INS spectrum was collected upon cooling to $<10 \mathrm{~K}$. The sample was warmed to $130{ }^{\circ} \mathrm{C}\left(5{ }^{\circ} \mathrm{C} / \mathrm{min}\right.$ ramping $)$ in a flow of $\mathrm{H}_{2}$ to conduct the hydrogenation under a flow of $\mathrm{H}_{2}$ for 1 hour. The cell was then quenched in liquid $\mathrm{N}_{2}$ and flushed briefly with dry $\mathrm{He}$ to remove any remaining $\mathrm{H}_{2}$ in the cell and weakly adsorbed $\mathrm{H}_{2}$ on the catalyst. An INS spectrum was collected upon cooling to $<10 \mathrm{~K}$. The sample was then heated to $250{ }^{\circ} \mathrm{C}$ $\left(5{ }^{\circ} \mathrm{C} / \mathrm{min}\right.$ ramping) under a flow of $\mathrm{H}_{2}$ to achieve the reduction of $\mathrm{CoO}$ to $\mathrm{Co}$ for 3.5 hours. The cell was then flushed with dry He and an INS spectrum was collected upon cooling to $<10 \mathrm{~K}$. The sample was warmed to $130{ }^{\circ} \mathrm{C}\left(5^{\circ} \mathrm{C} / \mathrm{min}\right.$ ramping $)$ in a flow of $\mathrm{H}_{2}$ to conduct the hydrogenation under a flow of $\mathrm{H}_{2}$ for 1 hour. The cell was then quenched in liquid $\mathrm{N}_{2}$ and flushed briefly with dry He to remove any remaining $\mathrm{H}_{2}$ in the cell and weakly adsorbed $\mathrm{H}_{2}$ on the catalyst. An INS spectrum was collected upon cooling to $<10 \mathrm{~K}$. 


\section{Density functional theory studies}

In this work, all spin-polarized DFT calculations were carried out using the Vienna Ab-initio Simulation Package $(\mathrm{VASP})^{48}$. The projector augmented wave (PAW) method $^{49}$ and the Perdew-Burke-Ernzerhof $(\mathrm{PBE})^{50}$ functional under the generalized gradient approximation (GGA $)^{51}$ were applied throughout the calculations. The kinetic energy cut-off was set to $400 \mathrm{eV}$, and the force threshold in structure optimization was $0.05 \mathrm{eV} / \AA$. We used a large vacuum gap of $15 \AA$ to eliminate the interactions between neighboring slabs. By adopting these calculation settings, the optimized lattice constant of $\mathrm{CoO}$ is $4.248 \AA$, which is in good agreement with the experimental value of $4.267 \AA^{52}$.

The transition states (TS) of surface reactions were located using a constrained optimization scheme and were verified when (i) all forces on the relaxed atoms vanish and (ii) the total energy is a maximum along the reaction coordination but it is a minimum with respect to the rest of the degrees of freedom ${ }^{53-55}$. The adsorption energy of species $\mathrm{X}$ on the surface $\left(\mathrm{E}_{\mathrm{ads}}(\mathrm{X})\right)$ was calculated with

$$
\mathrm{E}_{\text {ads }}(\mathrm{X})=-\left(\mathrm{E}_{\mathrm{X} / \mathrm{slab}}-\mathrm{E}_{\mathrm{slab}}-\mathrm{E}_{\mathrm{X}}\right)
$$

where $E_{X / s l a b}$ is the calculated total energy of the adsorption system, while $E_{\text {slab }}$ and $E_{X}$ are calculated energies of the clean surface and the gas phase molecule X, respectively. Obviously, a positive value of $E_{a d s}(X)$ indicates an exothermic adsorption process, and the more positive the $E_{a d s}(X)$ is, the more strongly the adsorbate $\mathrm{X}$ binds to the surface.

The oxygen vacancy formation energy $\left(\mathrm{E}_{\mathrm{OV}}\right)$ was calculated according to

$$
\mathrm{E}_{\mathrm{OV}}=\mathrm{E}_{\text {slab-OV }}+1 / 2 \mathrm{E}_{\mathrm{O} 2}-\mathrm{E}_{\text {slab }}
$$

where $E_{\text {slab-Ov }}$ is the total energy of the surface with one oxygen vacancy, and $\mathrm{E}_{02}$ is the energy of a gas phase $\mathrm{O}_{2}$ molecule.

For the model construction, we built a $p(2 \times 3)$ surface slab containing five atomic layers for the $\mathrm{CoO}(100)$ surface, and the top four $\mathrm{CoO}$ layers of the $\mathrm{CoO}(100)$ were allowed to fully relax, while the bottom two atomic layers were kept fixed to mimic the bulk region. A $2 \times 2 \times 1 k$-point mesh was used in calculations of all these models. Note that the on-site Coulomb interaction correction is necessary for the appropriate description of the Co $3 d$ electrons, and all calculations are performed with $\mathrm{U}=5.1 \mathrm{eV}$ and $\mathrm{J}=1.0 \mathrm{eV}$, which are consistent with the values determined by previous studies ${ }^{56,57}$. 
In addition, we tested the effect of the spin state of $3 d$ electrons in $\mathrm{Co}^{2+}$ in the optimization of $\mathrm{CoO}$, and found that the high-spin antiferromagnetic arrangement was the most stable state, and the calculated magnetic moment of $2.74 \mu \mathrm{B}$ obtained from the difference in spin-up and spin-down densities is consistent with literature reports ${ }^{58-60}$.

Date availability. The data supporting the findings of this study are available within the article, or available from the authors upon reasonable request.

\section{References}

1. Zhang, Z., Song, J. \& Han, B. Catalytic transformation of lignocellulose into chemicals and fuel products in ionic liquids, Chem. Rev. 117, 6834-6880 (2017).

2. Sun, Z., Fridrich, B., de Santi, A., Elangovan, S. \& Barta, K. Bright side of lignin depolymerization: toward new platform chemicals, Chem. Rev. 118, 614-678 (2018).

3. Chen, S., Wojcieszak, R., Dumeignil, F., Marceau, E. \& Royer, S. How catalysts and experimental conditions determine the selective hydroconversion of furfural and 5-hydroxymethylfurfural, Chem. Rev. 118, 11023-11117 (2018).

4. Roman-Leshkov, Y., Barrett, C. J., Liu, Z. Y. \& Dumesic, J. A., Production of dimethylfuran for liquid fuels from biomass-derived carbohydrates, Nature 447, 982-985 (2007).

5. Maki-Arvela, P., Ruiz, D., \& Murzin, D. Y. Catalytic hydrogenation/hydrogenolysis of 5hydroxymethylfurfural to 2,5-dimethylfuran, ChemSusChem 14, 150-168 (2021).

6. Hu, L., Lin, L., \& Liu, S. Chemoselective hydrogenation of biomass-derived 5-hydroxymethylfurfural into the liquid biofuel 2,5-dimethylfuran, Ind. Eng. Chem. Res. 53, 9969-9978 (2014).

7. Zu, Y., Yang, P., Wang, J., Liu, X., Ren, J., Lu, G. \& Wang, Y. Efficient production of the liquid fuel 2,5-dimethylfuran from 5-hydroxymethylfurfural over $\mathrm{Ru} / \mathrm{Co}_{3} \mathrm{O}_{4}$ catalyst, Appl. Catal. B: 
Environ. 146, 244-248 (2014).

8. Yang, P., Cui, Q., Zu, Y., Liu, X., Lu, G. \& Wang, Y. Catalytic production of 2,5-dimethylfuran from 5-hydroxymethylfurfural over $\mathrm{Ni} / \mathrm{Co}_{3} \mathrm{O}_{4}$ catalyst, Catal. Commun. 66, $55-59$ (2015).

9. Thananatthanachon, T., \& Rauchfuss, T. B. Efficient production of the liquid fuel 2,5dimethylfuran from fructose using formic acid as a reagent, Angew. Chem. Int. Ed. 49, 6616-6618 (2010).

10. Wang, G.-H., Hilgert, J., Richter, F. H., Wang, F., Bongard, H.-J., Spliethoff, B., Weidenthaler, C., \& Schüth, F. Platinum-cobalt bimetallic nanoparticles in hollow carbon nanospheres for hydrogenolysis of 5-hydroxymethylfurfural, Nat. Mater. 13, 293-300 (2014).

11. Esteves, L. M., Brijaldo, M. H., Oliveira, E. G., Martinez, J. J., Rojas, H., Caytuero, A., Passos, \& F. B. Effect of support on selective 5-hydroxymethylfurfural hydrogenation towards 2,5dimethylfuran over copper catalysts, Fuel 270, 117524 (2020).

12. Van Lent, R., Auras, S. V., Cao, K., Walsh, A. J., Gleeson, M. A., \& Juurlink, L. B. F. Site-specific reactivity of molecules with surface defects-the case of $\mathrm{H}_{2}$ dissociation on Pt, Science, 363, 155157 (2019).

13. Liu, P. X., Zhao, Y., Qin, R. X., Mo, S. G., Chen, G. X., Gu, L., Chevrier, D. M., Zhang, P., Guo, Q., Zang, D. D., Wu, B.,H., Fu, G. \& Zheng, N.,F. Photochemical route for synthesizing atomically dispersed palladium catalysts, Science, 352, 797-801 (2016).

14. Ye, T. N., Xiao, Z., Li, J., Gong, Y., Abe, H., Niwa, Y., Sasase, M., Kitano, M. \& Hosono, H. Stable single platinum atoms trapped in sub-nanometer cavities in $12 \mathrm{CaO} .7 \mathrm{Al}_{2} \mathrm{O}_{3}$ for chemoselective hydrogenation of nitroarenes, Nat. Commun. 11, 1020 (2020).

15. Li, S., Dong, M., Yang, J., Cheng, X., Shen, X., Liu, S., Wang, Z.Q., Gong, X. Q., Liu, H. \& Han, 
B. Selective hydrogenation of 5-(hydroxymethyl)furfural to 5-methylfurfural over single atomic metals anchored on $\mathrm{Nb}_{2} \mathrm{O}_{5}$, Nat. Commun. 12, 584 (2021).

16. Zhang, Z., Wang, Z.-Q., Li, Z., Zheng, W.-B., Fan, L., Zhang, J., Hu, Y.-M., Luo, M.-F., Wu, X.P., Gong, X.-Q., Huang, W. \& Lu, J.-Q. Metal-free ceria catalysis for selective hydrogenation of crotonaldehyde, ACS Catal. 10, 14560-14566 (2020).

17. Zhang, S., Huang, Z. Q., Ma, Y., Gao, W., Li, J., Cao, F., Li, L., Chang, C. R. \& Qu, Y. Solid frustrated-Lewis-pair catalysts constructed by regulations on surface defects of porous nanorods of $\mathrm{CeO}_{2}$, Nat. Commun. 8, 15266 (2017).

18. Li, Z., Werner, K., Chen, L., Jia, A., Qian, K., Zhong, J. Q., You, R., Wu, L., Zhang, L. Pan, H., Wu, X. P., Gong, X. Q., Shaikhutdinov, S., Huang, W. \& Freund, H. J. Interaction of hydrogen with ceria: hydroxylation, reduction, and hydride formation on the surface and in the bulk, Chem. Eur. J. 27, 5268-5276 (2021).

19. Joubert, J., Salameh, A., Krakoviack, V., Delbecq, F., Sautet, P., Coperet, C. \& Basset, J. M. Heterolytic Splitting of $\mathrm{H}_{2}$ and $\mathrm{CH}_{4}$ on $\gamma$-alumina as a structural probe for defect sites, J. Phys. Chem. B 110, 23944-23950 (2006).

20. Gribov, E. N., Bertarione, S., Scarano, D., Lamberti, C., Spoto, G. \& Zecchina, A. Vibrational and thermodynamic properties of $\mathrm{H}_{2}$ adsorbed on $\mathrm{MgO}$ in the $300-20 \mathrm{~K}$ interval, J. Phys. Chem. B 108, $16174-16186(2004)$

21. Zhao, Y., Rousseau, R., Li, J. \& Mei, D. Theoretical study of syngas hydrogenation to methanol on the polar Zn-terminated ZnO (0001) surface. J. Phys. Chem. C 116, 15952-15961 (2012).

22. Wu, Z., Xiong, F., Wang, Z. \& Huang, W. Thermal-, photo- and electron-induced reactivity of hydrogen species on rutile $\mathrm{TiO}_{2}(110)$ surface: role of oxygen vacancy. Chin. Chem. Lett. 29, $752-$ 
756 (2018).

23. Nagpure, A. S., Venugopal, A. K., Lucas, N., Manikandan, M., Thirumalaiswamy, R. \& Chilukuri, S. Renewable fuels from biomass-derived compounds: Ru-containing hydrotalcites as catalysts for conversion of HMF to 2,5-dimethylfuran, Catal. Sci. Technol. 5, 1463-1472 (2015).

24. Gao, Z., Fan, G., Liu, M., Yang, L. \& Li, F. Dandelion-like cobalt oxide microsphere-supported RuCo bimetallic catalyst for highly efficient hydrogenolysis of 5-hydroxymethylfurfural, Appl. Catal. B: Environ. 237, 649-659 (2018).

25. Li, Q., Man, P., Yuan, L., Zhang, P., Li, Y. \& Ai, S. Ruthenium supported on CoFe layered double oxide for selective hydrogenation of 5-hydroxymethylfurfural, Mol. Catal. 431, 32-38 (2017).

26. Gan, T., Liu, Y., He, Q., Zhang, H., He, X. \& Ji, H. Facile synthesis of kilogram-scale Co-alloyed Pt single-atom catalysts via ball milling for hydrodeoxygenation of 5-hydroxymethylfurfural, $A C S$ Sustainable Chem. Eng. 8, 8692-8699 (2020).

27. Shi, J., Wang, Y., Yu, X., Du, W. \& Hou, Z. Production of 2,5-dimethylfuran from 5hydroxymethylfurfural over reduced graphene oxides supported Pt catalyst under mild conditions, Fuel 163, $74-79$ (2016).

28. Goyal, R., Sarkar, B., Bag, A., Siddiqui, N., Dumbre, D., Lucas, N., Bhargava, S. K. \& Bordoloi, A. Studies of synergy between metal-support interfaces and selective hydrogenation of HMF to DMF in water, J. Catal. 340, 248-260 (2016).

29. Saha, B., Bohn, C. M. \& Abu-Omar, M. M. Zinc-assisted hydrodeoxygenation of biomass-derived 5-hydroxymethylfurfural to 2,5-dimethylfuran, ChemSusChem, 7, 3095-3101 (2014).

30. Kong, X., Zhu, Y., Zheng, H., Dong, F., Zhu, Y., \& Li, Y.-W. Switchable synthesis of 2,5dimethylfuran and 2,5-dihydroxymethyltetrahydrofuran from 5-hydroxymethylfurfural over 
Raney Ni catalyst, $R S C A d v$. 4, 60467-60472 (2014).

31. Gyngazova, M. S., Negahdar, L., Blumenthal, L. C. \& Palkovits, R. Experimental and kinetic analysis of the liquid phase hydrodeoxygenation of 5-hydroxymethylfurfural to 2,5-dimethylfuran over carbon-supported nickel catalysts, Chem. Eng. Sci. 173, 455-464 (2017).

32. Chen, M.-Y., Chen, C.-B., Zada, B. \& Fu, Y. Perovskite type oxide-supported Ni catalysts for the production of 2,5-dimethylfuran from biomass-derived 5-hydroxymethylfurfural, Green Chem. 18, 3858-3866 (2016).

33. Yang, P. P., Xia, Q. N., Liu, X. H. \& Wang, Y. Q. High-yield production of 2,5-dimethylfuran from 5-hydroxymethylfurfural over carbon supported Ni-Co bimetallic catalyst, J. Energy Chem. 25, 1015-1020 (2016).

34. Yang, P. P., Xia, Q. N., Liu, X. H. \& Wang, Y. Q. Catalytic transfer hydrogenation/hydrogenolysis of 5-hydroxymethylfurfural to 2,5-dimethylfuran over Ni-Co/C catalyst, Fuel 187, 159-166 (2017).

35. Chen, B. B., Li, F., Huang, Z. \& Yuan, G. Carbon-coated Cu-Co bimetallic nanoparticles as selective and recyclable catalysts for production of biofuel 2,5-dimethylfuran, Appl. Catal. B: Environ. 200, 192-199 (2017).

36. Li, D., Liu, Q., Zhu, C., Wang, H., Cui, C., Wang, C. \& Ma, L. Selective hydrogenolysis of 5hydroxymethylfurfural to 2,5-dimethylfuran over $\mathrm{Co}_{3} \mathrm{O}_{4}$ catalyst by controlled reduction, J. Energy Chem. 30, 34-41 (2019).

37. Xiao, T., Liu, X., Xu, G. \& Zhang, Y. Phase tuning of $\mathrm{ZrO}_{2}$ supported cobalt catalysts for hydrodeoxygenation of 5-hydroxymethylfurfural to 2,5-dimethylfuran under mild conditions, Appl. Catal. B: Environ. 295, 120270 (2021).

38. Bottari, G., Kumalaputri, A. J., Krawczyk, K. K., Feringa, B. L., Heeres, H. J. \& Barta, K. Copper- 
zinc alloy nanopowder: a robust precious-metal-free catalyst for the conversion of 5hydroxymethylfurfural, ChemSusChem 8, 1323-1327 (2015).

39. Srivastava, S., Jadeja, G. C. \& Parikh, J. Synergism studies on alumina-supported copper-nickel catalysts towards furfural and 5-hydroxymethylfurfural hydrogenation, J. Mol. Catal. A-Chem 426, 244-256 (2017).

40. Seemala, B., Cai, C. M., Wyman, C. E. \& Christopher, P. Support induced control of surface composition in $\mathrm{Cu}-\mathrm{Ni} / \mathrm{TiO}_{2}$ catalysts enables high yield $\mathrm{Co}$-conversion of $\mathrm{HMF}$ and furfural to methylated furans, ACS Catal. 7, 4070-4082 (2017).

41. Luo, J., Yun, H., Mironenko, A. V., Goulas, K., Lee, J. D., Monai, M., Wang, C., Vorotnikov, V., Murray, C. B., Vlachos, D. G., Fornasiero, P. \& Gorte, R. J. Mechanisms for high selectivity in the hydrodeoxygenation of 5-hydroxymethylfurfural over PtCo nanocrystals, ACS Catal. 6, 4095-4104 (2016).

42. Luo, J., Lee, J. D., Yun, H., Wang, C., Monai, M., Murray, C. B., Fornasiero, P. \& Gorte, R. J. Base metal-Pt alloys: A general route to high selectivity and stability in the production of biofuels from HMF, Appl. Catal. B: Environ. 199, 439-446 (2016).

43. Zhang, S., Shan, J., Zhu, Y., Nguyen, L., Huang, W., Yoshida, H., Takeda, S. \& Tao, F. Restructuring transition metal oxide nanorods for $100 \%$ selectivity in reduction of nitric oxide with carbon monoxide, Nano Lett. 13, 3310-3314 (2013).

44. Chin, R. L. \& Hercules, D. M. Surface spectroscopic characterization of cobalt-alumina catalysts, J. Phys. Chem. 86, 360-367 (1982).

45. Noronha, F. B., Schmal, M., Moraweck, B., Delichère, P., Brun, M., Villain, F. \& Fréty, R. Characterization of niobia-supported palladium-cobalt catalysts, J. Phys. Chem. B, 104, 5478-5485 
(2000).

46. Antonov, V. E., Antonova, T. E., Fedotov, V. K., Hansen, T., Kolesnikov, A. I. \& Ivanov, A. S. Neutron scattering studies of -CoH, J. Alloy. Compd. 404-406, 73-76 (2005).

47. Polo-Garzon, F., Fung, V., Nguyen, L., Tang, Y., Tao, F., Cheng, Y., Daemen, L. L., Ramirez-Cuesta, A. J., Foo, G. S. \& Zhu, M. Elucidation of the reaction mechanism for high-temperature water gas shift over an industrial-type copper-chromium-iron oxide catalyst, J. Am. Chem. Soc. 141, 79907999 (2019).

48. Kresse, G. \& Furthmüller, J. Efficient iterative schemes for ab initio total-energy calculations using a plane-wave basis set. Phys. Rev. B 54, 11169-11186 (1996).

49. Blöchl, P. E. Projector augmented-wave method. Phys. Rev. B 50, 17953-17979 (1994).

50. Perdew, J. P., Burke, J. \& Ernzerhof, M. Generalized gradient approximation made simple. Phys. Rev. Lett. 77, 3865-3868 (1996).

51. Teter, M. P., Payne, M. C. \& Allan, D. C. Solution of schrodinger's equation for large systems. Phys. Rev. B 40, 12255-12263 (1989).

52. Redman, M. J. \& Steward, E. G. Cobaltous oxide with the zinc blende/wurtzite-type crystal structure. Nature 193, 867-867 (1962).

53. Alavi, A., Hu, P., Deutsch, T., Silvestrelli, P. L. \& Hutter, J. CO oxidation on Pt(111): An Ab initio density functional theory study. Phys. Rev. Lett. 80, 3650-3653 (1998).

54. Liu, Z. P. \& Hu, P. General rules for predicting where a catalytic reaction should occur on metal surfaces: A density functional theory study of C-H and C-O bond breaking/making on flat, stepped, and kinked metal surfaces. J. Am. Chem. Soc. 125, 1958-1967 (2003).

55. Michaelides, A., Liu, Z. P., Zhang, C. J., Alavi, A., King, D. A. \& Hu, P. Identification of general linear relationships between activation energies and enthalpy changes for dissociation reactions at surfaces. J. Am. Chem. Soc. 125, 3704-3705 (2003).

56. Archer, T., Hanafin, R. \& Sanvito, S., Magnetism of $\mathrm{CoO}$ polymorphs: density functional theory and monte carlo simulations. Phys. Rev. B 78, 014431(2008). 
57. Pickett, W. E., Erwin, S. C. \& Ethridge, E. C. Reformulation of the LDA+U method for a localorbital basis. Phys. Rev. B 58, 1201-1209 (1998).

58. Solovyev, I. V., Liechtenstein, A. I. \& Terakura, K. Is hund's second rule responsible for the orbital magnetism in solids? Phys. Rev. Lett. 80, 5758-5761 (1998).

59. Rödl, C., Fuchs, F., Furthmüller, J. \& Bechstedt, F. Quasiparticle band structures of the antiferromagnetic transition-metal oxides $\mathrm{MnO}, \mathrm{FeO}, \mathrm{CoO}$, and NiO. Phys. Rev. B 79, 235114 (2009).

60. Wdowik, U. D. \& Parlinski, K., Lattice dynamics of $\mathrm{CoO}$ from first principles. Phys. Rev. B 75, 104306 (2007).

\section{Acknowledgments}

This project was supported financially by the National Natural Science Foundation of China (No. 21832002, 21872050, 21808063), Shanghai Municipal Science and Technology Major Project (Grant No.2018SHZDZX03) and the Programme of Introducing Talents of Discipline to Universities (B16017). This research used Beamline VISION at the Spallation Neutron Source, a DOE Office of Science User Facility operated by the Oak Ridge National Laboratory.

\section{Author contributions}

S.X., L.D., X.H.L. and Y.G.: preparation and characterization of catalysts, and performing the catalytic reactions. Z.Q.W. and X.Q.G.: DFT calculations. X.H., L.L.D., Y.C., A.J. R.-C. and S.Y.: collection and analysis of neutron scattering data. S.Y., X.Q.G. and Y.Q.W.: overall direction of the project. S.X., L.D., S.Y. and Y.Q.W. wrote the manuscript with the help from all authors.

\section{Additional information}

Supplementary information is available in the online version of the paper. Reprints and permissions information is available online at www.nature.com/reprints. 


\section{Competing financial interests}

The authors declare no competing financial interests.

\section{Author Information}

Correspondence and requests for materials should be addressed to SY (Sihai.Yang@manchester.ac.uk),

XQG (xgong@ecust.edu.cn) or YQW (wangyanqin@ecust.edu.cn). 